OPEN ACCESS

International Journal of

Environmental Research and

Public Health

ISSN 1660-4601

www.mdpi.com/journal/ijerph

Article

\title{
Irrigation Water Quality for Leafy Crops: A Perspective of Risks and Potential Solutions
}

\author{
Ana Allende ${ }^{1}$ and James Monaghan ${ }^{2, *}$
}

1 Research Group on Quality, Safety and Bioactivity of Plant Foods, Department of Food Science and Technology, CEBAS-CSIC, Campus Universitario de Espinardo, 30100 Murcia, Spain;

E-Mail: aallende@cebas.csic.es

2 Fresh Produce Research Centre, Department of Crop and Environment Sciences, Harper Adams University, Newport, Shropshire, TF10 8NB, UK

* Author to whom correspondence should be addressed; E-Mail: jmmonaghan@harper-adams.ac.uk; Tel.: +44-1952-820-280.

Academic Editors: Mieke Uyttendaele, Eelco Franz and Oliver Schlüter

Received: 4 June 2015 / Accepted: 29 June 2015 / Published: 3 July 2015

\begin{abstract}
There is increasing evidence of the contribution of irrigation water in the contamination of produce leading to subsequent outbreaks of foodborne illness. This is a particular risk in the production of leafy vegetables that will be eaten raw without cooking. Retailers selling leafy vegetables are increasingly targeting zero-risk production systems and the associated requirements for irrigation water quality have become more stringent in regulations and quality assurance schemes (QAS) followed by growers. Growers can identify water sources that are contaminated with potential pathogens through a monitoring regime and only use water free of pathogens, but the low prevalence of pathogens makes the use of faecal indicators, particularly E. coli, a more practical approach. Where growers have to utilise water sources of moderate quality, they can reduce the risk of contamination of the edible portion of the crop (i.e., the leaves) by treating irrigation water before use through physical or chemical disinfection systems, or avoid contact between the leaves and irrigation water through the use of drip or furrow irrigation, or the use of hydroponic growing systems. This study gives an overview of the main problems in the production of leafy vegetables associated with irrigation water, including microbial risk and difficulties in water monitoring, compliance with evolving regulations and quality standards, and summarises the current alternatives available for growers to reduce microbial risks.
\end{abstract}


Keywords: leafy vegetables; irrigation water; food safety; QAS; GAP; water disinfection treatment; hydroponics

\section{Introduction}

Water of inadequate quality has the potential to be a direct source of contamination and a vehicle for spreading localized contamination in the field, facility or transportation environments in the production of fresh produce crops [1]. A number of comprehensive review articles have been published which highlight irrigation water as a source of pathogenic microorganisms in produce [2-8]. Pathogenic microorganisms associated with irrigation water include bacteria, viruses and parasites (protozoa and helminths). Although viruses and parasites are of paramount importance and can be transmitted to fresh produce via irrigation water, this paper focuses on pathogenic bacteria.

The increasing evidence of contamination of produce from irrigation water has been reviewed recently by Uyttendaele et al. [9] and contamination events were identified where water is a risk factor in the production and harvesting of fresh produce. However, the authors made clear that identification of the implicated food vehicle and/or the location of the point of food contamination in fresh produce-associated outbreaks are a recurrent challenge.

Despite this evidence, research focused on microbial quality of agricultural water is relatively limited. Most research regarding microbial quality of water (e.g., pathogen prevalence or indicator organisms) has been conducted for objectives related to reclaimed water, drinking and recreational water supplies and the effects of agriculture on the environment [10]. In 2011, Pachepsky et al. [5] highlighted that no databases on microbial quality of irrigation water had been compiled. However, there is an increasing number of recent research papers that focus on the evaluation of the microbial quality of irrigation water used for the production of fresh produce and its significance as a source of contamination e.g., [11-20]. Several of these published papers show the results obtained within the frame of a research project consortium of the FP7 project Veg-i-Trade (www.vegitrade.org) focused on the impact of climate change and globalisation on safety of fresh produce.

Growers use a variety of water sources for field operations and irrigation and much knowledge is needed to relate risk factors associated with the transfer coefficients for pathogens by source, concentration and use [10]. Quantitative microbial risk assessment (QMRA) is being applied to establish the links between concentrations of pathogenic microorganisms in agricultural water and the probability of illness [21-23]. Lately, as a result of several longitudinal microbiological surveys, different scenarios have been evaluated to estimate the potential impact of agricultural practices, including water treatments and the application of potable water, on the E. coli levels and prevalence of pathogenic microorganisms in fresh produce [24,25].

Based on this evidence, standards and guidelines for Quality Assurance Schemes (QAS) have been designed to cultivate prevention and control of food safety hazards [26] but QAS have become not only a prevention strategy but also a marketing strategy used by the industry, which is pushing towards zero-risk for many factors including irrigation water sources, in response to consumers concerns over food safety [27]. In many cases, current QAS require growers to develop and implement management 
systems and to risk assess the irrigation water sources to reduce microbial risks. Increasingly QAS are requiring stringent testing regimes of water coming into contact with the edible portion of leafy vegetables [28]. However, some studies highlight that the required monitoring programs can be self-defeating and create additional uncompensated monitoring costs [26].

Growers should also consider other alternatives to guarantee the safety of the produce they produced under any circumstance. Surface water represents one of the most risky water sources, thus where growers are utilising surface water for agricultural applications, particularly for leafy greens or produce that is intended to be consumed raw, and mitigation strategies may be required [29]. Several strategies have been proposed to reduce the risk of produce contamination with pathogens during irrigation [5]. The main aims of these strategies is to reduce the use of uncontrolled sources of water and to establish distance limits for water resources used for irrigation from livestock housing, stored effluents, and/or land spread with manure [30].

Water treatment is also a feasible strategy to guarantee the microbial quality of irrigation water. Treating water during storage and while in the delivery systems may represent a good alternative to high frequency microbial testing [8] and probably the only possibility for growers using irrigation water with microbial loads above regulatory thresholds. Another option for growers using water sources of poor microbiological quality is the use of different production systems, such as hydroponic systems and drip irrigation, which avoid contact between the edible part of the crop and the irrigation water.

This study gives an overview of the main problems associated with irrigation water, including microbial risk and difficulties in water monitoring, compliance with evolving regulations and quality standards, and summarises the current alternatives available for growers to reduce microbial risks.

\section{Irrigation Water as a Risk Factor}

Agricultural water has been defined as a major risk factor in the contamination of leafy crops eaten raw as salads [30]. When available, fresh water is consumed for agricultural production but water scarcity is becoming a major threat to the sustainability of agriculture, which needs to rely much more on marginal water sources, including treated wastewater [31]. However, little is known regarding the microbial quality of irrigation water used for leafy crop production. Systematic sampling focused on determining the risks of microbial contamination associated with different water sources are rare and most of the existing information comes from U.S. The available literature indicates that generic E. coli levels and prevalence of pathogenic foodborne bacteria in irrigation water significantly varies depending on several factors including seasonality, geographical location and weather conditions among others (reviewed by [8,9]). The Center for Produce Safety [10] have published a report to provide a summary of the scientific and technical information related to factors that affect the microbiological safety of agricultural water. This report summarizes the most recent research on irrigation water and gives a good overview of the needs for future research including sampling strategies that provide an estimate of the true underlying distribution of bacteria in a water system, correlation of field and water system management practices with pathogen prevalence in agricultural water samples, as well as a better understanding of risk factors leading to survival and/or growth of pathogens on fresh produce following application of contaminated water. 
Table 1. Enumeration of microbial indicators and prevalence of foodborne pathogens in water used to irrigate fresh produce in Europe.

\begin{tabular}{|c|c|c|c|c|c|c|}
\hline Country & Produce & Water Source & Microorganisms & Average cfu/100 mL & Prevalence & Reference \\
\hline \multirow[t]{4}{*}{ Belgium } & Strawberry & Groundwater & STEC & - & $0 / 22$ & Delbeke et al., 2015 \\
\hline & & & E. coli spp. & 1 & $4 / 22$ & \\
\hline & & Rainfall water collected in ponds & STEC & - & $11 / 56$ & \\
\hline & & & E. coli spp. & $40-45$ & $40 / 56$ & \\
\hline \multirow[t]{4}{*}{ Belgium } & Lettuce & $\begin{array}{l}\text { Rainfall water collected in open } \\
\text { wells and bore hole water }\end{array}$ & STEC & - & $6 / 68$ & Holvoet et al., 2014 \\
\hline & & & Campylobacter spp. & - & $37 / 120$ & \\
\hline & & & Salmonella spp. & - & $1 / 68$ & \\
\hline & & & E. coli spp. & $30-35$ & $90 / 120$ & \\
\hline \multirow[t]{3}{*}{ Spain } & Baby spinach & $\begin{array}{l}\text { Surface water collected in } \\
\text { water reservoirs }\end{array}$ & STEC & - & $0 / 50$ & Castro-Ibañez et al., 2015 \\
\hline & & & Salmonella spp. & - & $1 / 50$ & \\
\hline & & & E. coli spp. & $5-10$ & $72 / 250$ & \\
\hline \multirow[t]{8}{*}{ Spain } & Tomatoes & Surface water & STEC & - & $0 / 16$ & López-Gálvez et al., 2014 \\
\hline & & & Salmonella spp. & - & $1 / 16$ & \\
\hline & & & E. coli spp. & $20-25$ & $6 / 32$ & \\
\hline & & & Listeria spp. & $30-35$ & $26 / 30$ & \\
\hline & & Reclaimed water & STEC & - & $0 / 16$ & \\
\hline & & & Salmonella spp. & - & $2 / 16$ & \\
\hline & & & E. coli spp. & $240-280$ & $31 / 32$ & \\
\hline & & & Listeria spp. & $350-400$ & $26 / 30$ & \\
\hline \multirow[t]{2}{*}{ Italy } & Tomatoes & Tap water & E. coli spp. & - & $0 / 30$ & Forslund et al., 2012 \\
\hline & & Reclaimed water & E. coli spp. & 10,300 & $11 / 30$ & \\
\hline \multirow[t]{2}{*}{ Crete } & Tomatoes & Tap water & E. coli spp. & 400 & $2 / 31$ & \\
\hline & & Reclaimed water & E. coli spp. & 596 & $4 / 31$ & \\
\hline
\end{tabular}


Table 2. Characteristics, advantages and disadvantages of water treatment technologies for irrigation water.

\begin{tabular}{|c|c|c|c|c|c|}
\hline Water Treatment & Active Agent & $\begin{array}{l}\text { Recommended } \\
\text { Dose }\end{array}$ & $\begin{array}{l}\text { Reported Microbial } \\
\text { Reductions Range } \\
(\text { Log cfu/mL) }\end{array}$ & Advantages & Disadvantages \\
\hline Sodium hypochlorite & $\begin{array}{l}\text { Hypochlorous } \\
\text { acid }\end{array}$ & $2-5 \mathrm{mg} / \mathrm{L}$ & $0.2-4.0$ & $\begin{array}{l}\text { High bactericidal action } \\
\text { Liquid ready to use } \\
\text { Low operating costs }\end{array}$ & $\begin{array}{l}\text { Organic matter reduces its efficacy } \\
\text { Influenced by } \mathrm{pH} \\
\text { Storage of large volumes } \\
\text { By-product formation (trihalomethanes and } \\
\text { chlorates among others) }\end{array}$ \\
\hline Calcium hypochlorite & $\begin{array}{l}\text { Hypochlorous } \\
\text { acid }\end{array}$ & $2-5 \mathrm{mg} / \mathrm{L}$ & $0.2-4.0$ & $\begin{array}{l}\text { High bactericidal action } \\
\text { Tablets ready to use } \\
\text { Low operating costs }\end{array}$ & $\begin{array}{l}\text { Organic matter reduces its efficacy } \\
\text { Influenced by } \mathrm{pH} \\
\text { By-product formation (trihalomethanes and } \\
\text { chlorates among others) }\end{array}$ \\
\hline Chlorine dioxide & $\begin{array}{l}\text { Chlorine dioxide } \\
\text { molecule }\end{array}$ & $0.1-5.0 \mathrm{mg} / \mathrm{L}$ & $0.5-5.0$ & $\begin{array}{l}\text { High bactericidal action } \\
\text { Effective at a wide } \mathrm{pH} \text { range (4-10) } \\
\text { Does not react with organic matter } \\
\text { as chlorine }\end{array}$ & $\begin{array}{l}\text { "in situ" generation or use of } \\
\text { stabilized solutions } \\
\text { By-product formation } \\
\text { (mostly chlorates) }\end{array}$ \\
\hline Ultrasound & Cavitation & $20-40 \mathrm{kHz}$ & 3.0 & $\begin{array}{l}\text { Not affected by } \mathrm{pH} \\
\text { Easy to use } \\
\text { No formation of disinfection by-products }\end{array}$ & Lack of residual bactericidal action \\
\hline UV-C & DNA damage & $1-200 \mathrm{~mJ} / \mathrm{cm}^{2}$ & $0.5-5.0$ & $\begin{array}{l}\text { High bactericidal action } \\
\text { Not affected by } \mathrm{pH} \\
\text { Easy to use } \\
\text { No formation of disinfection } \\
\text { by-products } \\
\text { Low operational costs }\end{array}$ & $\begin{array}{l}\text { Water turbidity affects efficacy } \\
\text { Lack of residual bactericidal action }\end{array}$ \\
\hline Membrane filtration & $\begin{array}{l}\text { Particle } \\
\text { interception }\end{array}$ & & $1.0-5.0$ & $\begin{array}{l}\text { Not affected by } \mathrm{pH} \\
\text { Easy to use } \\
\text { No formation of disinfection by-products }\end{array}$ & Filter blockage \\
\hline
\end{tabular}




\section{Current Situation in Europe}

Recently, a comprehensive review has summarized the main irrigation water sources used in Europe highlighting municipal water, rainwater, groundwater and surface water as the most relevant [9]. In a temperate production area, such as the UK, the primary sources of water for irrigation are reported to be surface water (54\%) and groundwater (41\%), with the remainder coming from public mains water, rainwater and other sources [32,33]. However, in arid and semi-arid parts of Europe, such as the South of Spain, Italy and Greece, which are confronting increasing water shortages, treated municipal wastewater is a valuable water source for recycling and reuse in agriculture. As an example, $347 \mathrm{hm}^{3}$ of treated wastewater were reused in 2010 in Spain, particularly in the South East of Spain where almost $60 \%$ of the reclaimed water produced was reused [34] and $233 \mathrm{hm}^{3}$ in Italy [35]. Although the use of untreated wastewater for crop production is not a recommended practice, research results indicate that tertiary water treatment, including final disinfection using UV light, chlorination and/or ultrasound have been shown to be effective in removal of indicator microorganisms and pathogens to below limits of detection [5,36].

Research related to microbial quality of agricultural water in Europe is limited, although recent research studies have highlighted the microbial risks associated with different water sources (Table 1). In most cases, longitudinal microbiological surveys have been carried out to evaluate the microbiological quality of produce samples, excluding the monitoring of risk factors such as irrigation water. It should be taken into account that the performance of irrigation water-quality monitoring and management practices are highly variable within countries as well as among different countries, with large differences across Europe. In 2006, Tyrrel et al. [37] reported that in UK, the majority of growers do not irrigate with water that would conform the European Union Drinking Water Standard [38] and used water that was faecally contaminated, but that typical faecal coliform concentrations were $\leq 1000 / 100 \mathrm{~mL}$. More recently, Holvoet et al. [16] monitored eight Belgian lettuce farms to establish the relationships between levels of indicator bacteria and detection of enteric zoonotic pathogens. A high prevalence $(75 \%, n=120)$ of $E$. coli was found in the irrigation water sources with $65 \%$ of the positive samples having $E$. coli levels $\geq 1 \log \mathrm{cfu} / 100 \mathrm{~mL}$ while $26 \%$ of the samples showed $E$. coli counts $\geq 2 \log \mathrm{cfu} / 100 \mathrm{~mL}$, which is above most of the irrigation water-quality standards. Additionally, $35 \%$ of the collected samples were positive for at least one pathogen (Salmonella, Campylobacter or Shiga toxin-producing E. coli (STEC)). In this study, most of the monitored farms used open wells to hold collected rainfall water. Previously reported E. coli values for surface water collected from rivers within an agricultural landscape were within the range 1.5-3.3 $\log \mathrm{cfu} / \mathrm{mL}$ [39], confirming the evidence that surface water, including rivers, streams, and creeks have unpredictable water quality and activities upstream can rapidly change the levels of contaminants [9]. A study focused on Belgian strawberry production reported significant differences in the microbiological quality of irrigation water obtained from different water sources including groundwater and collected rainfall water stored in ponds [19]. They reported that water obtained from the ponds was positive for E. coli (40/56) with an average level of $1.6 \mathrm{log} \mathrm{cfu} / 100 \mathrm{~mL}$ and almost $20 \%$ of these samples were positive for STEC. However, groundwater samples showed much lower levels of E. coli and these samples did not contain STEC. Water stored in reservoirs or lagoons provides both an opportunity for pathogen die-off through natural UV but also for new contamination associated with the use of reservoirs as wildlife habitats [37]. 
In many European countries, a significant proportion of irrigation water is abstracted and stored in farm reservoirs. Castro-Ibañez et al. [17] monitored several water reservoirs used to irrigate growing fields of leafy greens. Samples were analysed for presence of foodborne pathogens and only one sample was positive for Salmonella spp. Reported E. coli prevalence and concentration in irrigation water samples from water reservoirs was lower than that reported from open wells in Belgium. Observed differences between Belgium and Spain might be due to differences in weather conditions as solar radiation has been highlighted as an important mechanism for bacterial decline in environmental samples including irrigation water [18]. Urban wastewater has been used in agriculture as a way to overcome water scarcity in the South of Europe. The European Water Framework Directive [40], specifies that treated wastewater should be used in agriculture where and whenever possible. Currently, urban wastewater is mainly used for irrigation in combination with production systems that avoid direct contact between the water and the edible part of the fresh produce. In countries such as Spain, Greece and Italy, commercial production using urban wastewater as irrigation water usually involves production of tomatoes, peppers and cucumbers grown hydroponically in greenhouses. Sometimes, wastewater treatment plants, consisting of a train of individual unit processes, are located close to the greenhouse (Figure 1).

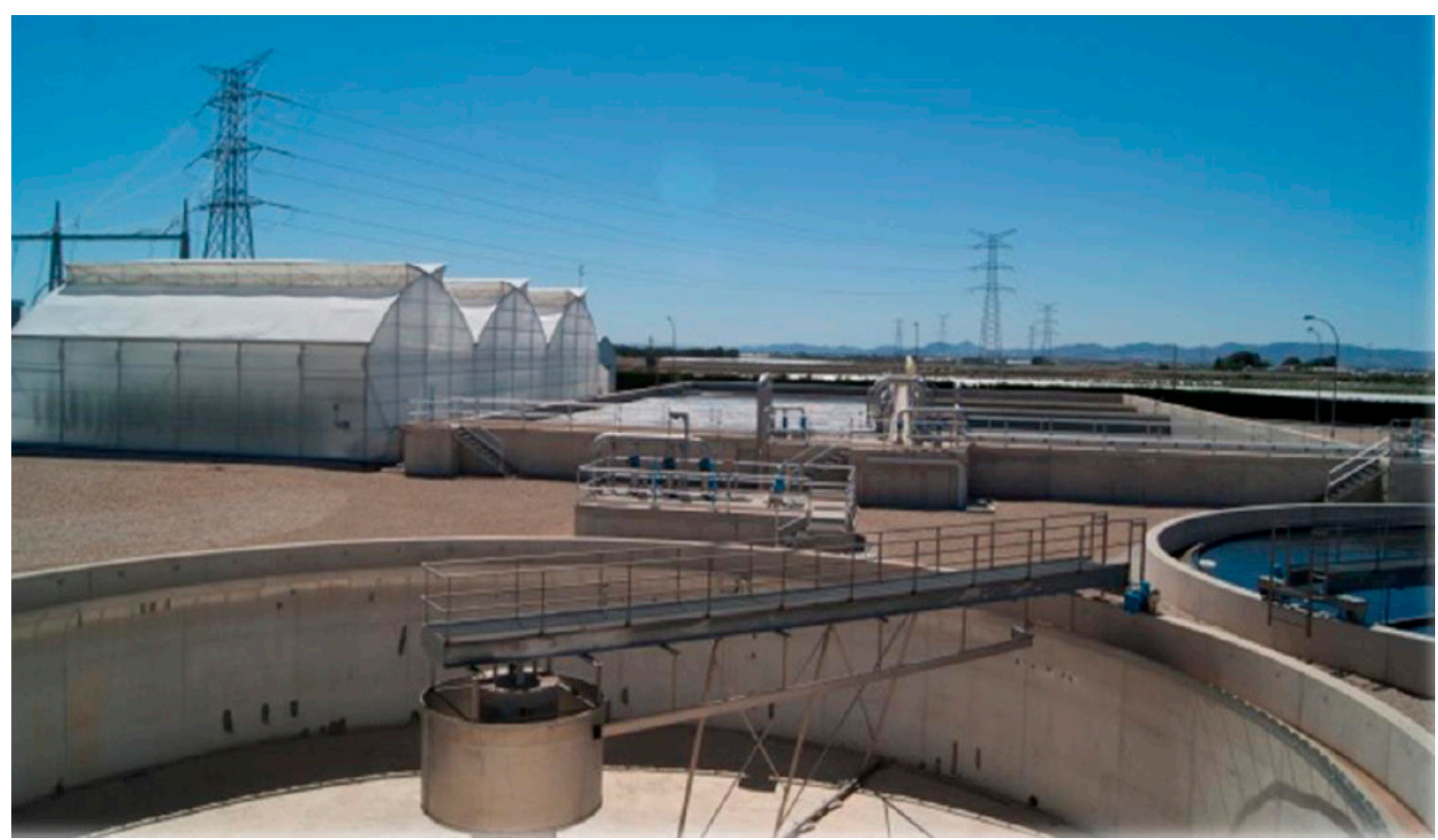

Figure 1. A secondary treatment wastewater plant located in a greenhouse production unit to provide irrigation water for tomato production. Reprinted with permission of Quality and Safety Lab CEBAS-CSIC.

Studies focusing on the microbial quality of reclaimed water used for irrigation reported presence of faecal contamination within the range $2-4 \log E$. coli $\mathrm{cfu} / 100 \mathrm{~mL}$ and also presence of pathogenic microorganisms such as Salmonella spp. [41,42] (Table 1). Production systems that minimize irrigation water contact with the edible portion of the crop seem to reduce the risk of contamination. Codex Alimentarius [43] reported that plants grown in hydroponic systems absorb nutrients and water at varying rates, constantly changing the composition of the re-circulated nutrient solution and because 
of this water used in hydroponic culture should be changed frequently, or if recycled, should be treated to minimize microbial and chemical contamination.

\section{Regulations, Guidelines and Microbial Quality Standards for Water Used in Primary Production}

The microbial quality of irrigation water has been related with food safety for more than 25 years. In Europe, specific microbial criteria are only currently established in guidelines and quality assurance standards (QAS), but specific microbial criteria have been introduced in U.S. legislation and these are starting to have an impact on European standards.

\subsection{Legislation-The European Commission}

Regulation (EC) No 852/2004 on the hygiene of foodstuffs defines potable water as "meeting the minimum requirements laid down in Council Directive 98/83/EC [38] on the quality of water intended for human consumption", clean water is defined in Regulation (EC) No. 852/2004 [44], as "clean seawater and fresh water of a similar quality" and clean seawater is defined as "natural, artificial or purified seawater or brackish water that does not contain micro-organisms, harmful substances or toxic marine plankton in quantities capable of directly or indirectly affecting the health quality of food" [44]. Specific microbiological criteria are not defined but growers must be able to demonstrate that their operations are managed in a way that controls food safety risks, including those associated with the use of water.

\subsection{Guidelines}

\subsubsection{World Health Organization (WHO)}

Whilst it was clear that care was needed in the safety of water used to irrigate crops that are eaten raw, such as leafy salads; prior to 1973 there was no generally accepted standard of microbial water quality. In 1973 the World Health Organization (WHO) addressed the issue that drinking water microbial quality standards (i.e., $\leq 2.2 \mathrm{cfu} / 100 \mathrm{~mL}$ coliforms) were not a realistic target and produced a guideline value of $\leq 100 \mathrm{cfu} / 100 \mathrm{~mL}$ coliforms for unrestricted irrigation water (i.e., water used to irrigate crops that will be eaten uncooked) derived from wastewater [45]. Following consideration of what was achievable by wastewater treatment processes and associated epidemiological studies of wastewater use, these guidelines were revised in 1989 to a geometric mean of $\leq 1000 \mathrm{cfu} / 100 \mathrm{~mL}$ faecal coliforms and an arithmetic mean of $\leq 1 / \mathrm{L}$ intestinal nematode during the irrigation period [46]. These standards have been criticised, particularly from those developing guidelines with the aim for "zero-risk" irrigation water [47]. The WHO has more recently changed the approach and there are now no definitive values for microbiological guidelines for irrigation water. Instead, irrigation water safety should be based upon risk assessment as recommended in WHO documents and water guidelines in advanced economies should rely on in-country standards [48,49]. 


\subsubsection{Codex Alimentarius Commission}

Baseline guidance on safety requirements of irrigation water is provided through Codex Alimentarius: both the General Principles of Food Hygiene-CAC/RCP 1-1969 [50] and the Code of hygienic practice for fresh fruit and vegetables-CAC/RCP 53-2003 [42] address the issue. However this only provides a "general framework of recommendations [...] rather than providing detailed recommendations for specific agricultural practices..." [43] i.e., the water used in primary production must be safe. However the microbial requirements are not defined. For example, in the Leafy Green annex of the Code of hygienic practice for fresh fruit and vegetables-CAC/RCP 53-2003 growers are required to "seek appropriate guidance on water quality and delivery methods to minimize the potential for contamination with microbial pathogens" [43]. And where water comes in to "substantial contact with the edible portion of the leafy vegetable should meet the standards for potable or clean water" [43] where these are defined as: Potable water-water which meets the quality standards of drinking water such as described in the WHO Guidelines for Drinking Water Quality; Clean water-water that does not compromise food safety in the circumstances of its use [43].

\subsection{Microbial Quality Standards for Water Used in Primary Production}

\subsubsection{QAS-1st Generation}

In the early 1990s the UK fresh produce supply chain started to develop Quality Assurance Schemes (QAS) also known as Retailer Codes of Practice partly in response to the 1990 UK Food Safety Act that required growers to be treated as running food businesses within a consolidated supply and as a consequence growers were exposed to due diligence imposed from the retail end of the supply chain [51,52]. Amongst these QAS were Assured Produce-1991; Tesco Natures Choice-1992 and, more widely relevant, EurepGAP-1997 [53]. In essence these QAS followed Codex guidelines and required systems to be in place to ensure that the water used in production was safe. The approach followed Hazard Analysis and Critical Control Point (HACCP) principles such as to risk assess water sources and use but did not define water quality criteria. In 2004 Marks and Spencer (M\&S) released a new QAS "Field to Fork" that required growers to test their irrigation water for E. coli, but again no criteria were stipulated as to what an acceptable level of indicator organism would be [53].

\subsubsection{QAS—-2nd Generation}

The QAS increased their focus on microbial risks associated with irrigation water and a new generation of schemes (e.g., Red Tractor Fresh Produce Scheme, GlobalGAP, Tesco Nurture, M\&S Field to Fork version 2) was developed in the 2000s [51]. As with the first generation of schemes, growers were still required to develop and implement management systems along HACCP principles and to risk assess all water sources. There was also more guidance on risk assessment methodology but critical levels of indicator organisms (with some confusion between E. coli and faecal coliforms) in water used in primary production were now defined. Generally, the criteria were based on the WHO guidance for water for irrigation of produce that can be consumed uncooked of $\leq 1000$ 
faecal coliforms cfu/100 mL with an additional reporting level of $\geq 400 \mathrm{cfu} / 100 \mathrm{~mL}$ in Tesco Nurture and M\&S Field to Fork version 2, which has become more stringent in later revisions for leafy crops.

\subsubsection{QAS—-3rd Generation}

In 2011 the Food Safety Modernization Act (FSMA) became US law [54]. The FSMA proposed microbial quality standards for irrigation water and wash water that came into contact with the edible portion of fresh produce crops. Although the original microbial quality standards are being revised to include rules on produce safety that are more flexible and less burdensome in key areas [55], these standards have been applied in Good Agricultural Practices (GAP) used in the USA and also more widely. One example is the McDonalds GAP [28] where the grower is required to implement systems to ensure food safety, based on HACCP principles and risk assessment as with previous generations of QAS, but clear metrics and microbial criteria are now defined. Irrigation water that may contact the edible portion of the crop must have no more than $235 \mathrm{cfu}$ (or most probable number (MPN), as appropriate) generic E. coli per $100 \mathrm{~mL}$ for any single sample, or a rolling geometric mean $(n=5)$ of more than $126 \mathrm{cfu}$ (or MPN, as appropriate) generic E. coli per $100 \mathrm{~mL}$ of water [28]. A pre-planting water sampling programme is needed for any irrigation water used (and stored rain water). Each water source must have a minimum of one sample analyzed from the point of application closest to the crop to establish that water quality is acceptable before being used for irrigating the crop (i.e., $\leq 235 \mathrm{cfu}$ generic E. coli per $100 \mathrm{~mL}$ ). Subsequently, during crop growth, a set of at least five irrigation water samples must be collected prior to harvest to establish the rolling geometric mean. The sampling frequency is not stipulated but five samples must be taken within the crop growth period or 30 days, whichever is the shorter [28].

More recently the FDA has revised the upper limit of the irrigation water quality criteria to a statistical threshold value (i.e., a value that should not be exceeded by more than 10 percent of the samples taken) $\leq 410 \mathrm{CFU}$ of generic E. coli in $100 \mathrm{~mL}$ of water [55] and it would be anticipated that this standard would start to be used in some QAS.

It has become clear that the industry is being pushed towards zero-risk irrigation water sources in response to supply chain concerns over food safety and that there is a greater requirement for frequent water testing regimes with complex calculations of critical values. These high standards will be difficult to achieve with open water sources such as rivers or stored water that are regularly tested, and for some producers their water sources will not comply with the requirements. This may lead to alternative strategies being required.

\section{Solutions}

\subsection{Monitoring Pathogen and Indicator Species in Water Sources}

Testing water can be used to establish a history of microbiological quality and inform a risk ranking for a water source [9]. The prohibitive cost and time requirement of pathogen detection make microbial indicators a good strategy to characterize microbial contamination in agricultural water [56]. Several studies report that indicator bacteria, and particularly generic E. coli concentrations, are not correlated with the presence of pathogens such as E. coli O157 or Salmonella spp. in water samples, 
suggesting that $E$. coli data might not be suitable to predict the risk of exposure to pathogenic strains $[10,57,58]$. However, a logistic regression analysis of samples taken monthly for 12 months from 18 locations throughout Central Florida showed that E. coli concentration can predict the probability of enumerating selected Salmonella levels, indicating that E. coli provides a reasonable way to predict Salmonella levels in surface water. According to this, in recent longitudinal microbial surveys carried out in Europe, presence of elevated levels of E. coli increased the probability of presence of pathogens (STEC and Salmonella spp.) [16,18]. Additionally, Wilkes et al. [59] reported that faecal indicators such as $E$. coli spp. were conservative surrogates for a variety of pathogenic microorganisms in surface waters within an agricultural landscape. Based on these reports, E. coli spp. could be identified as suitable for a hygiene criterion at primary production of leafy greens and can be applied for validation and verification studies of GAP.

However, factors such as the dynamic nature of agricultural water microbial quality, the time lag between obtaining agricultural water testing results and water use, and the fact that current water sampling strategies are based on an assumption that bacteria are floating as single cells in water, make water monitoring limited in its ability to monitor microbial risks [10]. In addition, Won et al. [60] reported that $n>5$ canal and $n>14$ reservoir samples were needed to calculate $E$. coli concentrations at a precision level of $85 \%$ with $95 \%$ confidence interval under the same environmental conditions during the testing period; a frequency much greater than required by the most stringent QAS. The frequency of testing will vary depending on the water source and the risk of environmental contamination [3]. For example, Holvoet et al. [61] observed in a study of leafy vegetable farms in Belgium that contamination of irrigation water was more prevalent in open-field production compared to greenhouse production. An additional limitation of the testing approach is the costs of an effective monitoring program which are usually too expensive for most small to medium growers [9]. Hence, alternatives to monitoring sampling plans such as water treatments and the selection of less risky production systems, which avoid contact between the edible part of the plant and irrigation water, may be an alternative option in reducing microbial risks to leafy vegetables.

\subsection{Water Treatments}

Physical and chemical disinfection systems have been explored as methods to remove human pathogens from agricultural water sources (Table 2), although disinfection treatment of irrigation water is still a very limited practice [4]. Nowadays, chemical sanitizers are the most commonly used water treatments, although environmentally friendly alternatives are being demanded, particularly for organic production. In fact, concerns have risen recently regarding both the absence of water treatment and the excessive use of potentially toxic chemicals to treat irrigation water. Norton-Brandão et al. [35] presented a critical review of a wide range of urban reclamation technologies that could be applied to water; of these, the treatments relevant to agricultural irrigation water included coagulation, flocculation, filtration and chemical disinfection [8].

Among commercially available water treatments, chlorine-based sanitizer remains the most common water treatment used for the removal of biohazards from irrigation water $[4,8]$. The advantages of using water treatment are generally associated with microbial reductions of both foodborne pathogens as well as phytopathogens and the reduction of contamination from biofilm 
formation in the irrigation pipes (Table 2) [61]. There are many inexpensive commercial applications of chlorine-based sanitizers available for growers. When using this type of water disinfectants, a key step is the estimation of the peak chlorine demand over a range of typical operating conditions, where the peak chlorine demand is defined as the maximum amount of free chlorine in a batch of water that is "used up" by soil and organic materials added with product during washing [62]. Two of the more widespread treatments in Europe and also U.S., are calcium hypochlorite or chlorine dioxide but limitations of chlorine-based disinfectant in terms of formation of disinfection by-products and the potential negative effect on the environment have limited its use in agricultural water. Nevertheless, the goal of the dosing system is, in most cases, to reduce E. coli levels to be within a compliant range, for which a minimal dose of disinfectant is usually enough. This reduces the potential detrimental effects on the farm soil or environment from disinfection by-products [63] in the short-term but there are still concerns for chronic effects of large-scale use over long periods of time [4]. Additionally, the volumes of water that are commonly used in a medium-large production field are very high $\left(50-100 \mathrm{~m}^{3}\right)$, and the cost associated to the treatment of irrigation water can be substantial.

Greener technologies based on physical treatments such as ultrasound (US), ultraviolet light (UV-C) and filtration have been successfully tested to reduce microbial loads of irrigation water $[4,29,36]$. US technology has the advantage of reducing microbial loads, including algae, without the detrimental effects of the formation of disinfection by-products [36]. Other reported advantages of US include potential simultaneous oxidation, thermolysis, shear degradation, and enhanced mass transfer processes [64]. UV-C light has also been used frequently to disinfect irrigation water and requires the installation of a UV-C treatment system where water passes through a vessel while it is illuminated by UV-C lamps located in the vessel (Figure 2). These systems are usually relatively cheap and represent a good treatment option if water turbidity is low [65]. However, a pre-treatment usually based on sand filtration and also regular maintenance of the lamp are needed to ensure proper efficacy of the system. Membrane and sand filtration have been reported as effective technologies to remove pathogens from water [35]. Different pore sizes are applied for different applications. Thus, membrane filters classified as micro- $(0.1-10 \mu \mathrm{m})$, ultra $(0.002-0.1 \mu \mathrm{m})$, nano $(0.0005-0.002 \mu \mathrm{m})$ filtration or reverse osmosis $(<0.0005 \mu \mathrm{m})$ are used for removal of microorganisms while larger pore sizes and rapid sand filters are used to reduce soil and plant material that may clog the membrane filters [66]. Membrane filtration is more effective at controlling pathogens when combined in a series of multi-stage filters and in combination with other treatments that have other modes of action such as chlorine [67]. Innovative filtration systems such filters containing sand and/or materials with reactive components have been explored as potential water treatments [10]. Slow sand filtration controls microorganisms present in the water by biological, physical and chemical reactions. In these systems, microbial removal is carried out by a complex microbial community located in the upper layer on the sand bed but also by physically entrapping the pathogens and debris [67]. Biosand filter zero-valent iron incorporated (ZVI) treatments, which have been used in permeable reactive barriers to remove a broad range of chemical contaminants in groundwater, have also been reported as potential water treatments [68]. Ingram et al. [69] have recently proposed ZVI treatment as a cost-effective mitigation option for irrigation water to help small farmers reduce risk of foodborne $E$. coli infections associated with contamination of leafy greens. 
Whilst alternative systems are being proposed in scientific studies, the evaluation of the site-specific applicability of any of these technologies, such as maintenance costs, safety, and biological effects on crops and humans, is missing [4,5]. In general, water treatment technologies for agricultural water have not been deeply evaluated and in most of the cases, operational and maintenance costs are knowledge gaps crucial to the decision making process of farmers [4]. On the other hand, process control for water treatment technologies is mandatory to guarantee the efficacy of the treatment. A good understanding and consistent implementation of systems to monitor, control, and document water treatment performance are needed because without the process control, all water treatment systems may give a "false confidence".

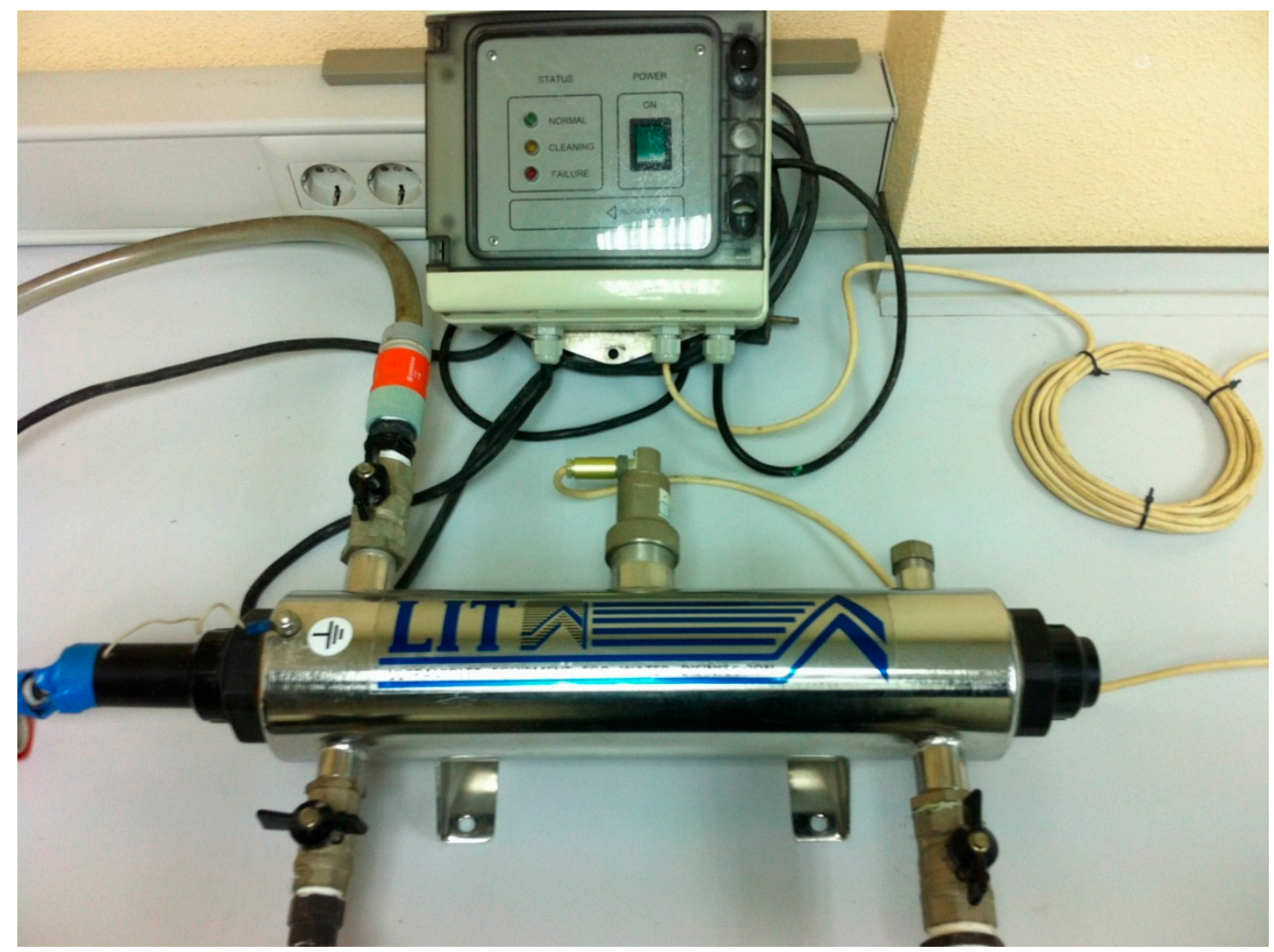

Figure 2. UV-C treatment system where water passes through a vessel while it is illuminated by UV-C lamps located in the vessel. Reprinted with permission of Quality and Safety Lab CEBAS-CSIC.

\subsection{Alternative Production Systems}

An alternative strategy to managing the risk of contaminating leafy vegetables through faecally contaminated irrigation water is to avoid direct contact with the edible parts of the crop. This can be achieved through selecting the irrigation method and/or the production system used to the crops. Application of microbial-contaminated irrigation water using subsurface drip irrigation has been shown to reduce contamination of crops including lettuce at harvest compared to furrow irrigation [70]. However, even if direct contact between irrigation water and the edible part of the leafy crop is avoided, irrigation water may contaminate the soil or substrate, where the bacteria can survive for some time [30] and irrigation or rainfall splash may contaminate the crop [11]. 
Soilless systems, such as hydroponic floating systems [71] or nutrient film techniques (NFT) [72], are being used for leafy vegetables with short production cycles allowing a better control and standardization of the cultivation process (Figure 3). Many advantages have been attributed to the use of soilless systems in greenhouses to produce leafy greens, but reductions in product quality and shelf life have been observed [73] which may limit the use of these systems. However, recent studies carried out in commercial agricultural production sites showed that the use of poor quality irrigation water combined with the use of soilless production systems considerably reduced microbial contamination risks to fresh produce $[42,74]$.

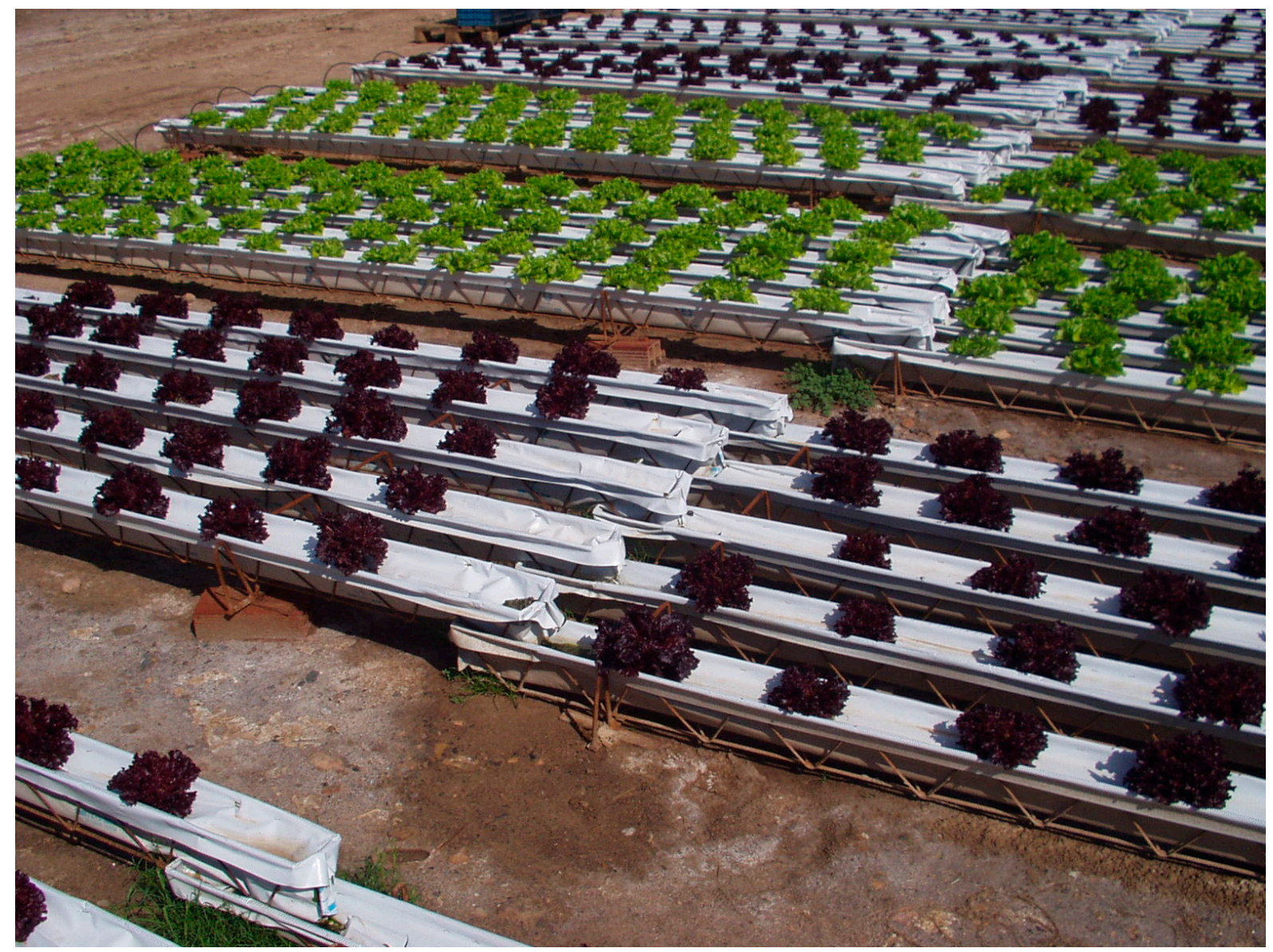

Figure 3. Nutrient film techniques (NFT), a type of soilless systems where a thin film of nutrient solution flows through plastic channels which contain the plant roots and laid on a slope in order to grant the constant flow of nutrient solution. Source: James M. Monaghan (Harper Adams University).

This reduction can be attributed to preventing contact between the irrigation water and the edible part of the plant. In a non-commercial hydroponic system lettuce grown using diluted effluent from secondary UV treated grey-water was shown to have an acceptable level of E. coli spp. on the harvested leaves, even though levels on the roots were high [75]. The use of alternative production systems such as greenhouses and hydroponics are assumed to be safer than open field production from the microbiological point of view due to the minimization of some risk factors associated with sources of pre-harvest contamination, but also a greater control of water disinfection with water being recirculated and cleaned periodically [76]. The nutrient solution, and hence water, used in soilless 
systems is one of the most important aspects for the success of leafy greens production [77] and the quality of water can be better controlled in soilless systems [63] both from a plant pathogen and human pathogen perspective. Nevertheless, before hydroponics could be used to grow crops using lower quality water more knowledge is required on the risks posed from root contamination and internalization of bacteria (e.g., [78]) from contaminated hydroponic water sources.

\section{Conclusions}

There is an increasing evidence of contamination of produce from irrigation water, but scarce information on the microbial quality of agricultural water is available. Despite this, retailers selling leafy vegetables are risk averse and are targeting zero-risk production systems. As a consequence the requirements for irrigation water quality and safety in QAS have evolved and become more stringent. One approach is for growers to identify water sources that are contaminated with potential pathogens through a monitoring regime and only use water free of pathogens, but this approach is very costly and ultimately does not ensure safe water. The use of faecal indicators, particularly E. coli, allows growers to identify water sources where there is a route of faecal contamination, allowing risk categorization of water sources $[9,30]$. Where growers only have access to water sources of moderate quality, with low levels of faecal contamination, they have two main options available to produce leafy vegetables that will not pose unacceptable risks to the consumer: treat water before use, using physical or chemical disinfection systems, with chlorine the most commonly used system currently; or reduce/eliminate contact with the leaves from irrigation water through irrigation water placement i.e., drip or furrow, or the use of soilless growing systems. It is likely that a combination of approaches will be needed to meet the microbial requirements of leafy vegetables and ensure safe food for consumers.

\section{Acknowledgments}

The authors are thankful for the financial support from the Center for Produce Safety Grant Agreement 2015-374 and the MINECO (Project AGL2013-48529-R). Support provided by the COST ACTION FA1202 BacFoodNet is also appreciated.

\section{Author Contributions}

Authors (Ana Allende and James Monaghan) have equally participated in this work via study of conception, acquisition of data, drafting of manuscript and/or critical revision.

\section{Conflicts of Interest}

The authors declare no conflict of interest.

\section{References}

1. Guide to minimize microbial food safety hazards for fresh fruits and vegetables. U.S. Department of Health and Human Services, Food and Drug Administration/Center for Food Safety and Applied Nutrition: Washington, DC, USA, 1998. 
2. Steele, M.; Odumeru, J. Irrigation water as source of foodborne pathogens on fruits and vegetables. J. Food Prot. 2004, 67, 2839-2849.

3. Gerba, C.P. The role of water and water testing in produce safety. In Microbial Safety of Fresh Produce; Fan, X., Niemira, B.A., Doona, C.J., Feeherty, F.E., Gravani, R.B., Eds.; Wiley: Indianapolis, IN, USA, 2009; pp. 129-142.

4. Suslow, T.V. Standards for irrigation and foliar contact water. Available online: http://extension. psu.edu/food/safety/farm/resources/water/standards-for-irrigation-and-foliar-contact-water/view (accessed on 28 May 2015).

5. Pachepsky, Y.; Shelton, D.R.; McLain, J.E.; Patel, J.; Mandrell, R.E. Irrigation waters as a source of pathogenic microorganisms in produce: A Review. Adv. Agron. 2011, 113, 73-138.

6. Olaimat, A.N.; Holley, R.A. Factors influencing the microbial safety of fresh produce: A review. J. Food Prot. 2012, 32, 1-19.

7. Park, S.; Szonyi, B.; Gautam, R.; Kendra, N.; Anciso, J.; Ivanek, R. Risk factors for microbial contamination in fruits and vegetables at the preharvest level: A systematic review. J. Food Prot. 2012, 75, 2055-2081.

8. Gil, M.I.; Selma, M.V.; Suslow, T.; Jacxsens, L.; Uyttendaele, M.; Allende, A. Pre- and postharvest preventive measures and intervention strategies to control microbial food safety hazards of fresh leafy vegetables. Crit. Rev. Food Sci. Nutr. 2015, 55, 453-468.

9. Uyttendaele, M.; Jaykus, L.A.; Amoah, P.; Chiodini A.; Cunliffe, D.; Jacxsens, L.; Holvoet, K.; Korsten, L.; Lau, M.; McClure, P.; et al. Microbial hazards in irrigation water: Standards, norms, and testing to manage use of water in fresh produce primary production. Compr. Rev. Food Sci. F 2015, 14, 336-356.

10. Agricultural Water: Five Year Research Review; Center for Produce Safety: Davis, CA, USA, 2014

11. Monaghan, J.M.; Hutchison, M.L. Distribution and decline of human pathogenic bacteria in soil after application in irrigation water and the potential for soil-splash-mediated dispersal onto fresh produce. J. Appl. Microbiol. 2012, 112, 1007-1019.

12. Oliveira, M.; Viñas, I.; Usall, J.; Anguera, M.; Abadias, M. Presence and survival of Escherichia coli $\mathrm{O} 157: \mathrm{H} 7$ on lettuce leaves and in soil treated with contaminated compost and irrigation water. Int. J. Food Microbiol. 2012, 156, 133-140.

13. Kisluk, G.; Yaron, S. Presence and persistence of Salmonella enterica serotype Typhimurium in the phyllosphere and rhizosphere of spray-irrigated parsley. Appl. Environ. Microbiol. 2012, 78, 4030-4036.

14. Van der Linden, I.; Cottyn, B.; Uyttendaele, M.; Vlaemynck, G.; Heyndrickx, M.M.; Maes, M. Survival of enteric pathogens during butterhead lettuce growth: Crop stage, leaf age, and irrigation. Foodborne Pathog. Dis. 2013, 10, 485-491.

15. Ceuppens, S.; Hessel, C.T.; de Quadros Rodrigues, R.; Bartz, S.; Tondo, E.C.; Uyttendaele, M. Microbiological quality and safety assessment of lettuce production in Brazil. Int. J. Food Microbiol. 2014, 181, 67-76.

16. Holvoet, K.; Sampers, I.; Seynnaeve, M.; Uyttendaele, M. Relationships among hygiene indicators and enteric pathogens in irrigation water, soil and lettuce and the impact of climatic conditions on contamination in the lettuce primary production. Int. J. Food Microbiol. 2014, 71, 21-31. 
17. Castro-Ibáñez, I.; Gil, M.I.; Tudela, J.A.; Ivanek, R.; Allende, A. Assessment of microbial risk factors and impact of meteorological conditions during production of baby spinach in the Southeast of Spain. Food Microbiol. 2015, 49, 173-181.

18. Castro-Ibáñez, I.; Tudela, J.A.; Gil, M.I.; Allende, A. Microbial safety considerations of flooding in primary production of leafy greens. Food Res. Int. 2015b, 68, 62-69.

19. Delbeke, S.; Ceuppens, S.; Holvoet, K.; Samuels, E.; Sampers, I.; Uyttendaele, M. Multiplex real-time PCR and culture methods for detection of Shiga toxin-producing Escherichia coli and Salmonella Thompson in strawberries, a lettuce mix and basil. Int. J. Food Microbiol. 2015, 193, 1-7.

20. Généreux, M.; Grenier, M.; Côté, C. Persistence of Escherichia coli following irrigation of strawberry grown under four production systems: Field experiment. Food Control 2015, 47, 103-107.

21. Stine, S.W.; Song, I.; Choi, C.Y.; Gerba, C.P. Application of microbial risk assessment to the development of standards for enteric pathogens in water used to irrigate fresh produce. J. Food Prot. 2005, 68, 913-918.

22. Mota, A.; Mena, K.D.; Soto-Beltran, M.; Tarwater, P.M.; Cháidez, C. Risk assessment of Cryptosporidium and Giardia in water irrigating fresh produce in Mexico. J. Food Prot. 2009, 72, 2184-2188.

23. Seidu, R.; Sjølander, I.; Abubakari, A.; Amoah, D.; Larbi, J.A.; Stenström, T.A. Modeling the die-off of E. coli and Ascaris in wastewater-irrigated vegetables: Implications for microbial health risk reduction associated with irrigation cessation. Water Sci. Techn. 2013, 68, 1013-1021.

24. Castro-Ibáñez, I.; Jacxsens, L.; Gil, M.I.; Uyttendaele, M.; Allende, A. Quantitative exposure assessment of Escherichia coli in baby spinach primary production in Spain: Effects of weather conditions and agricultural practices. Int. J. Food Microbiol. 2015, submitted.

25. Jacxsens, L.; Delbeke, S.; Ceuppens, S.; Johannessen, G.; Allende, A.; Sampers, I.; Uyttendaele, M. Comparative quantitative exposure modelling of enteric pathogens Salmonella and Shiga toxin producing Escherichia coli on fresh basil, strawberries and butterhead lettuce. Food Microbiol. 2015, submitted.

26. Parker, J.S.; Wilson, R.S.; LeJeune, J.T.; Rivers, L.; Doohan, D. An expert guide to understanding grower decisions related to fresh fruit and vegetable contamination prevention and control. Food Control 2012, 26, 107-116.

27. Fulponi, L. Private voluntary standards in the food system: The perspective of major food retailers in OECD countries. Food Policy 2006, 31, 1-13.

28. McDonald. McDonald's Good Agricultural Practices Food Safety Standards, Food Safety Checklist \& Produce Processing Guidelines-August 2012.

29. Jones, L.A.; Worobo, R.W.; Smart, C.D. UV light inactivation of human and plant pathogens in unfiltered surface irrigation water. Appl. Environ. Microb. 2014, 80, 849-854.

30. EFSA. Panel on Biological Hazards (BIOHAZ). Scientific opinion on the risk posed by pathogens in food of non-animal origin. Part 2 (Salmonella and Norovirus in leafy greens eaten raw as salads). EFSA J. 2014, 11. Available online: www.efsa.europa.eu/efsajournal (accessed on 16 May 2015).

31. Considering Water Quality for Use in the Food Industry; ILSI Europe Report Series; International Life Sciences Institute: Brussels, Belgium, 2008. 
32. Pond, K.; Charles, K.; Pedley, S. Review of the Use of Water in UK Agriculture and the Potential Risks to Food Safety; Report B17005; Food Standards Agency: London, UK, 2007.

33. Weatherhead, K. Water-Future Availability, Demand and Management. Available online: http://www.ofc.org.uk/files/ofc/papers/08weatherhead.pdf (accessed on 14 May 2015).

34. Pedrero, F.; Kalavrouziotis, I.; Alarcón, J.J.; Koukoulakis, P.; Asano, T. Use of treated municipal wastewater in irrigated agriculture-Review of some practices in Spain and Greece. Agric. Water Manag. 2010, 97, 1233-1241.

35. Norton-Brandão, D.; Scherrenberg, S.M.; van Lier, J.B. Reclamation of used urban waters for irrigation purposes - A review of treatment technologies. J. Environ. Manag. 2013, 122, 85-98.

36. Villanueva, M.V.; Luna, M.C.; Gil, M.I.; Allende, A. Ultrasound treatments improve the microbiological quality of water reservoirs used for the irrigation of fresh produce. Food Res. Int. $201575,140-147$

37. Tyrrel, S.F.; Knox, J.W.; Weatherhead, E.K. Microbiological water quality requirements for salad irrigation in the United Kingdom. J. Food Prot. 2006, 69, 2029-2035.

38. EC, European Commission. Council Directive 98/83/EC of 3 November 1998 on the quality of water intended for human consumption. Off. J. Eur. Commun. 1998, 5, 0032-0054.

39. Economou, V.; Gousia, P.; Kansouzidou, A.; Sakkas, H.; Karanis, P.; Papadopoulou, C. Prevalence, antimicrobial resistance and relation to indicator and pathogenic micro-organisms of Salmonella enterica isolated from surface waters within an agricultural landscape. Int. J. Hyg. Environ. Health. 2012, 216, 435-444.

40. EC, European Commission. European Water Framework Directive. Council Directive 2000/60/EC of 2nd December 2000. Available online: http://ec.europa.eu/environment/ water/water-framework/index_en.html (accessed on 1 June 2015).

41. Forslund, A.; Ensink, J.H.H.; Markussen, B.; Battilani, A.; Psarras, G.; Gola, S.; Sandei, L.; Fletcher, T.; Dalsgaard, A. Escherichia coli contamination and health aspects of soil and tomatoes (Solanum lycopersicum L.) subsurface drip irrigated with on-site treated domestic wastewater. Water Res. 2012, 46, 5917-5934.

42. Lopez-Galvez, F.; Allende, A.; Pedrero-Salcedo, F.; Alarcon, J.J.; Gil, M.I. Safety assessment of greenhouse hydroponic tomatoes irrigated with reclaimed and surface water. Int. J. Food Microbiol. 2014, 191, 97-102.

43. CAC (Codex Alimentarius Commission). Code of Hygienic Practice for Fresh Fruits and Vegetables. Available online: ftp://ftp.fao.org/codex/publications/Booklets/FreshFruitsVeg/ FFV_2007_EN.pdf (accessed on 16 May 2015).

44. European Commission. Regulation (EC) No 852/2004 of the European Parliament and of the Council of 29 April 2004 on the hygiene of foodstuffs. 2004. Available online: http://eurlex.europa.eu/LexUriServ/LexUriServ.do?uri=OJ:L:2004:139:0001:0054:en:PDF (accessed on 1 July 2015).

45. Reuse of effluents: Methods of wastewater treatment and public health safeguards. Report of a WHO Meeting of Experts, Technical Report Series No. 517; WHO: Geneva, Switzerland, 1973.

46. Health guidelines for the use of wastewater in agriculture and aquaculture. In Report of a WHO Scientific Group, Technical Report Series No. 778; WHO: Geneva, Switzerland, 1989. 
47. Havelaar, A.; Blumenthal, U.J.; Strauss, M.; Kay, D.; Bartram, J. Chapter 2-Guidelines: The current position. In Water Quality: Guidelines, Standards and Health; Fewtrell, L., Bartram, J., Eds.; IWA Publishing: London, UK, 2001; pp. 17-42.

48. WHO Third Edition of the WHO Guidelines for the Safe Use of Wastewater, Excreta and Greywater in Agriculture and Aquaculture: Guidance note for National Programme Managers and Engineers-Applying the Guidelines along the Sanitation Ladder, 2010. Available online: http://www.who.int/water_sanitation_health/wastewater/FLASH_OMS_WSHH_Guidance_note1 _20100729_17092010.pdf(accessed on 18 May 2015).

49. WHO. Third edition of the WHO Guidelines for the Safe Use of Wastewater, Excreta and Greywater in Agriculture and Aquaculture: Guidance Note for National Programme Managers-Guidelines for Drinking-Water Quality; In Health-based targets; 2010. Available online: http://www.unwater.org/wwd10/downloads/WHO_IWA/Health-Based_Targets_3_17_10.pdf (accessed on 18 May 2015).

50. Recommended International Code of Practice: General Principles of Food Hygiene. Available online: http://www.codexalimentarius.org/standards/list-of-standards/en/?provide= standards\&orderField=fullReference\&sort=asc\&num1=CAC/RCP (accessed on 16 May 2015).

51. Soon, J.M.; Baines, R.N. Public and private food safety standards: Facilitating or frustrating fresh produce growers? Laws 2013, 2, 1-19.

52. The Food Safety Act-A guide for businesses. 2015. Available online: https://www. food.gov.uk/sites/default/files/multimedia/pdfs/fsactguidefoodbusiness.pdf (accessed on 14 May 2015).

53. Monaghan, J.M. United Kingdom and European approach to fresh produce food safety and security. HortTechnics 2006, 16, 559-562.

54. FDA, Food and Drug Administration. Fact Sheets on the Subparts of the Original FSMA Proposed Rule for Produce Safety Standards for the Growing, Harvesting, Packing, and Holding of Produce for Human Consumption. Available online: http://www.fda.gov/Food/ GuidanceRegulation/FSMA/ucm334552.htm (accessed on 14 May 2015).

55. FDA, Food and Drug Administration. FSMA Proposed Rule for Produce Safety: Information on Specific Provisions. 2014. Available online: http://www.fda.gov/food/guidanceregulation/fsma/ ucm415226.htm\#water (accessed on 14 May 2015).

56. Park, S.; Navratil, S.; Gregory, A.; Bauer, A.; Srinath, I.; Jun, M.; Szonyi, B.; Nightingale, K.; Anciso, J.; Ivanek, R. Generic Escherichia coli contamination of spinach at the preharvest level: The role of farm management and environmental factors. Appl. Environ. Microbiol. 2013, 79, 4347-4358.

57. Shelton, D.R.; Karns, J.S.; Coppock, C.; Patel, J.; Sharma, M.; Pachepsky, Y A. Relationship between eae and stx virulence genes and $E$. coli in an agricultural watershed: Implications for irrigation water standards and leafy green commodities. J. Food Prot. 2011, 74, 18-23.

58. Benjamin, L.; Atwill, E.R.; Jay-Russell, M.; Cooley, M.; Carychao, D.; Gorski, L.; Mandrell, R.E. Occurrence of generic Escherichia coli, E. coli $\mathrm{O} 157$ and Salmonella spp. in water and sediment from leafy green produce farms and streams on the Central California coast. Int. J. Food Microbiol. 2013, 165, 65-76. 
59. Wilkes, G.; Edge, T.; Gannon, V.; Jokinen, C.; Lyautey, E.; Medeiros, D.; Neumann, N.; Ruecker, N.; Topp, E.; Lapen, D.R. Seasonal relationships among indicator bacteria, pathogenic bacteria, Cryptosporidium oocysts, Giardia cysts, and hydrological indices for surface waters within an agricultural landscape. Water Res. 2009, 43, 2209-2223.

60. Won, G.; Schlegel, P.J.; Schrock, J.M.; Lejeune, J.T. Absence of direct association between coliforms and Escherichia coli in irrigation water and on produce. J. Food Prot. 2013, 76, 959-966.

61. Holvoet, K.; Sampers, I.; Seynnaeve, M.; Jacxsens, L.; Uyttendaele, M. Agricultural and management practices and bacterial contamination in greenhouse vs. open field lettuce production. Int. J. Environ. Res. Public Health 2015, 12, 32-63.

62. Suslow, T. It's Time to "Farmer-Up". Available online: http://ucanr.edu/datastoreFiles/234-2605.pdf (accessed on 14 May 2015).

63. Benefits and Risks of the Use of Chlorine-Containing Disinfectants in Food Production and Food Processing: Report of a Joint FAO/WHO Expert Meeting; FAO/WHO: Ann Arbor, MI, USA, 2009; pp. 27-30.

64. Sharma, S.K.; Sanghi, R.; Mudhoo, A. Chapter 1-Green Practices to Save Our Precious "Water Resource". In Advances in Water Treatment and Pollution Prevention; Sharma, S.K., Sanghi, R., Eds.; Springer: Dordrecht, The Netherlands, 2012; pp. 1-36.

65. Newman, S.E. Disinfecting Irrigation Water for Disease Management. In Proceedings of 20th Annual Conference on Pest Management on Ornamentals, San Jose, CA, USA, 20-22 February 2004. Available online: http://ghex.colostate.edu/pdf_files/DisinfectingWater.pdf (accessed on 14 May 2015).

66. Van der Bruggen, B.; Vandecasteele, C.; van Gestel, T.; Doyen, W.; Leysen, R. A review of pressure-driven membrane processes in wastewater treatment and drinking water production. Environ. Prog. 2003, 22, 46-56.

67. Raudales, R.E.; Parke, J.L.; Guy, C.L.; Fisher, P.R. Control of waterborne microbes in irrigation: A review. Agric. Water Manag. 2014, 143, 9-28.

68. Meggyes, T.; Simon, G. Removal of organic and inorganic pollutants from groundwater using permeable reactive barriers Part2. Engineering of permeable reactive barriers. Land Contam. Reclam. 2000, 8, 175-187.

69. Ingram, D.T.; Callahan, M.T.; Ferguson, S.; Hoover, D.G.; Chiu, P.C.; Shelton, D.R.; Millner, P.D.; Camp, M.J.; Patel, J.R.; Kniel, K.E.; et al. Use of zero-valent iron biosand filters to reduce Escherichia coli O157: H12 in irrigation water applied to spinach plants in a field setting. J. Appl. Microbiol. 2012, 112, 551-560.

70. Song, I.; Stine, S.; Choi, C.; Gerba, C. Comparison of crop contamination by microorganisms during subsurface drip and furrow irrigation. J. Environ. Eng. 2006, 132, 1243-1248.

71. Nicola, S.; Hoeberechts, J.; Fontana, E. Comparison between traditional and soilless culture system to produce rocket (Eruca sativa) with low nitrate content. Acta Hortic 2005, 697, 549-555.

72. Benoit, F.; Ceustermans, N. Consequences of closed soilless growing systems for the recirculating nutrient solution and the production techniques. In Proceedings of the XXVI International Horticultural Congress: Protected Cultivation 2002: In Search of Structures, Systems and Plant Materials, Toronto, Canada, 2004; pp. 331-340. 
73. Manzocco, L.; Foschia, M.; Tomasi, N.; Maifreni, M.; Costa, L.D.; Marino, M.; Cortella, G.; Cesco, S. Influence of hydroponic and soil cultivation on quality and shelf life of ready-to-eat lamb's lettuce (Valerianella locusta L. Laterr). J. Sci. Food Agric. 2011, 91, 1373-1380.

74. Luedtke, A.N.; Chapman, B.; Powell, D.A. Implementation and analysis of an on-farm food safety program for the production of greenhouse vegetables. J. Food Prot. 2003, 66, 485-489.

75. Keller, R.; Perim, K.; Semionato, S.; Zandonade, E.; Cassini, S.; Goncalves, R.F. Hydroponic cultivation of lettuce (Lactuca sativa) using effluents from primary, secondary and tertiary + UV treatments. Water Sci. Technol.: Water Suppl. 2005, 5, 95-100.

76. Orozco, L.; Rico-Romero, L.; Escartín, E.F. Microbiological profile of greenhouses in a farm producing hydroponic tomatoes. J. Food Prot. 2008, 71, 60-65.

77. Soundy, P.; Cantliffe, D.J.; Hochmuth, G.J.; Sttofella, P.J. Nutrient requirements for lettuce transplants using a floatation irrigation system. I. Phosphorus. HortScience 2001, 36, 1066-1070.

78. Deering, A.J.; Mauer, L.J.; Pruitt, R.E. Internalization of E. coli O157: H7 and Salmonella spp. in plants: A review. Food Res. Int. 2012, 45, 567-575.

(C) 2015 by the authors; licensee MDPI, Basel, Switzerland. This article is an open access article distributed under the terms and conditions of the Creative Commons Attribution license (http://creativecommons.org/licenses/by/4.0/). 